\title{
Estimated billing system is the bane of grid electric power supply and development in Nigeria: An empirical analysis
}

\author{
Anthony C. Ohajianya (i) * \\ Department of Physics, Federal University of Technology, P. M. B. 1526, Owerri, Imo State, Nigeria
}

\section{ARTICLE INFO}

\section{Article history:}

Received 23 April 2021

Received in revised form 11 May 2021

Accepted 18 May 2021

Available online

4 July 2021

Keywords:

EEDC

Electricity

Estimated billing

Power

Prepaid meters

\begin{abstract}
The estimated billing system for electricity was introduced in Nigeria by the Nigerian Electricity Regulatory Commission (NERC) in 2012 for billing customers without meters or with faulty or inaccessible meters. But instead of following the guidelines and formula provided by NERC for the estimation, the electricity Distribution Companies (DisCos) resorted to billing these customers arbitrarily and frustrated efforts by NERC to ensure the proper metering of electricity consumers. This research evaluates the incentive, which makes the DisCos in Nigeria prefer the estimating billing system to a much more efficient smart prepaid metering system. To carry out the research, four Enugu Electricity Distribution Company (EEDC) customers were selected. The estimated bills of these customers, which they received before they got smart prepaid meters, were compared with their prepaid meter bills for an equal period. EEDC was found to be over-billing these customers under the estimated billing system by a yearly average per customer of 64,901.67 Nigerian Naira (170.79 USD).
\end{abstract}

\section{Introduction}

The three basic factors responsible for the poor and erratic grid electric power supply in Nigeria have been highlighted as inappropriate government policies; inefficiencies in power generation, transmission, distribution, and utilization; and use of incompetent staff by the power distribution companies [1]. Some other factors have been enumerated in literature $[2,3]$. If these factors are examined critically, it can be seen that inappropriate government policies are mainly responsible for the poor and erratic electricity supply in Nigeria. The Government has a duty to make good policies and ensure that the policies are implemented for the wellbeing of the populace and the economic growth of the nation.

Grid electric power supply system started in Nigeria in 1929 with the commencement of operation of the Nigeria Electricity Supply Company (NESCO) and the construction of a hydroelectric power station at Kurra near Jos [4]. NESCO was a privately owned hydroelectric power station and a utility company that supplied electricity to some locations mainly in Northern Nigeria $[5,6]$. The colonial administration in Nigeria took over NESCO in 1946 and transferred the business of electric power generation, transmission, distribution, and sales to the Electricity Corporation of Nigeria (ECN) after its establishment and commencement of operation in 1951 [7].

By an act of the Nigerian parliament, the Niger Dams Authority (NDA) was established in 1962 at the completion of the Niger Dam Hydroelectric Project at Kainji [4]. NDA was created to assume management of dam construction, hydropower generation, and maintenance while ECN focused on power

\footnotetext{
* Corresponding author

E-mail address: anthony.ohajianya@futo.edu.ng

https://doi.org/10.37121/jase.v5i1.157
}

2636-607X / 2736-0652 ( 2021 the authors. Published by Sciengtex. This is an open access article under CC BY-NC-ND license (http://creativecommons.org/licenses/by-nc-nd/4.0/) 
transmission, distribution, and sales. Following a series of power outages in the country and challenges between the ECN and NDA, the two bodies were merged in 1972 to form the National Electric Power Authority (NEPA). The merger did not bring about positive transformations as NEPA continued to perform poorly. Due to the poor performance, NEPA also went through transformations through the reform act of 2005 which unbundled it into 18 companies (comprising 6 generation companies, 1 transmission company, and 11 distribution companies) under the flagship of the Power holding company of Nigeria (PHCN) [8]. In addition to the establishment of PHCN, the Nigerian government also established and inaugurated the Nigerian Electricity Regulatory Commission (NERC) in November 2005. NERC was saddled with the responsibility of regulating the tariffs charged by $\mathrm{PHCN}$ and also monitoring the quality of services of the company [9]. PHCN was given the mandate to oversee the activities of the 18 companies for 5 years within which a privatization exercise would be carried out culminating in the full or partial privatization or concession of the companies by the end of the 5 years $[10,11]$. The privatization exercise faced setbacks and did not achieve its mandated goal within the stipulated 5 years due to poor management [12].

The Nigerian electric power sector privatization exercise succeeded in November 2013 with the handing over of the distribution companies (DisCos) under PHCN to private companies [13]. The six (6) generation companies (GenCos) comprising Afam Power Plc, Sapele Power Plc, Egbin Power Plc, Ughelli Power Plc, Kainji Power Plc, and Shiroro Power Plc, were either fully or partly privatized or concessioned as shown in Table 1 [14]. The Transmission Company of Nigeria (TCN) was reorganized to improve its reliability and expand its capacity. The Nigerian government has $100 \%$ ownership of the TCN while the eleven (11) distribution companies were fully privatized. The 11 DisCos and their coverage area in Nigeria are shown in Fig. 1 [15].

The Nigerian Government injected substantial capital into the power sector between 1999 and 2019 [12,16-18]. This amounted to 1.5 trillion Nigerian Naira in intervention funds into the power sector. Despite these investments, Nigeria's key energy indicators are still poor as shown in Table 2 [19]. Nigeria continues to experience frequent power outages with the attendant negative effect on economic activities as shown in Fig. 2 [20].

Table 1 The six GenCos and their privatization status [14].

\begin{tabular}{cccc}
\hline GenCo & $\begin{array}{c}\text { Installed capacity } \\
\text { (MW) }\end{array}$ & Type & Privatization status \\
\hline Afam Power Plc & 776 & Gas & $100 \%$ sold \\
Sapele Power Plc & 414 & Gas & $51 \%$ sold \\
Egbin Power Plc & 1,020 & Gas & $100 \%$ sold \\
Ughelli Power Plc & 900 & Gas & $100 \%$ sold \\
Kainji Power Plc & 1,338 & Hydro & Long term concession \\
Shiroro Power Plc & 600 & Hydro & Long term concession \\
\hline
\end{tabular}

Table 2 Nigeria's power generation capacity and energy consumption per capita as of 2017 compared to other World Economies [19].

\begin{tabular}{cccc}
\hline Country & $\begin{array}{c}\text { Generation capacity } \\
(\mathrm{GW})\end{array}$ & $\begin{array}{c}\text { Energy consumption per } \\
\text { capita } \\
\text { (kWh per person) }\end{array}$ & World rank \\
\hline USA & $1,084.0$ & 88124 & 12 \\
Germany & 214.0 & 49661 & 29 \\
UK & 103.0 & 36484 & 43 \\
South Africa & 51.0 & 29134 & 58 \\
China & $1,794.0$ & 28744 & 59 \\
Brazil & 157.0 & 17740 & 88 \\
Egypt & 55.0 & 12192 & 108 \\
Indonesia & 63.0 & 7916 & 132 \\
India & 388.0 & 6662 & 154 \\
Ghana & 4.4 & 2758 & 162 \\
Nigeria & 13.0 & 2365 & \\
\hline
\end{tabular}




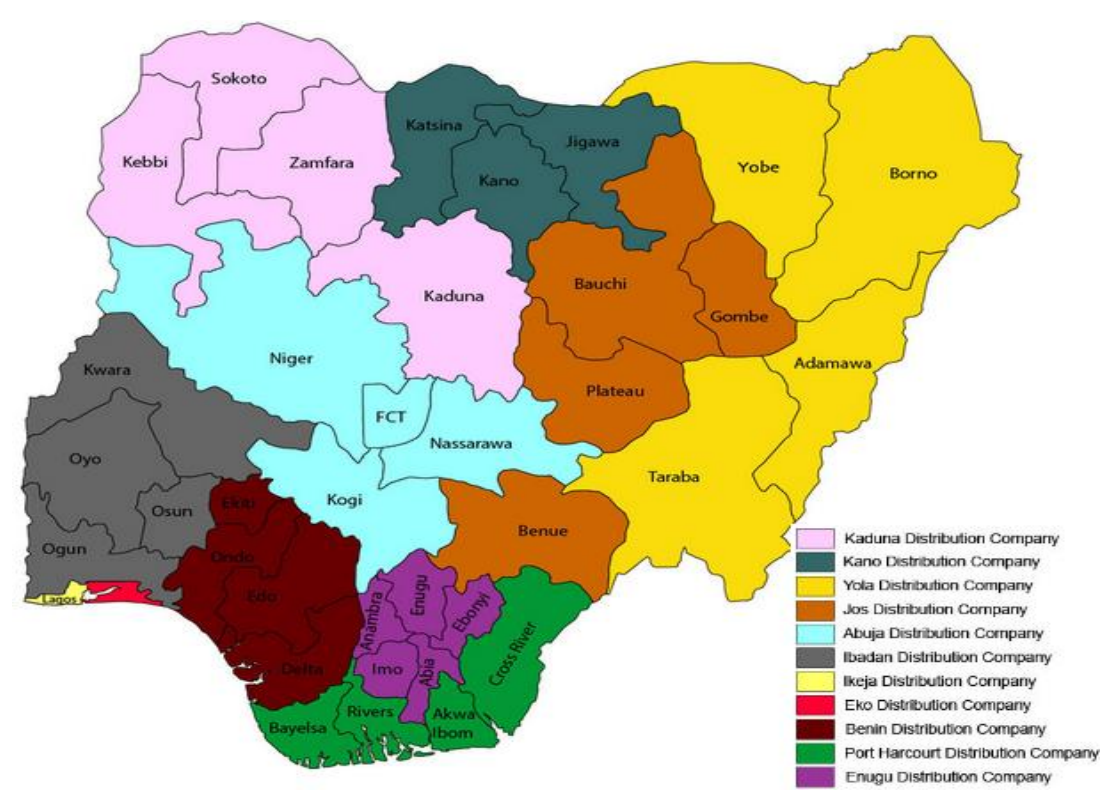

Fig. 1 The eleven DisCos in Nigeria and their coverage area [15].

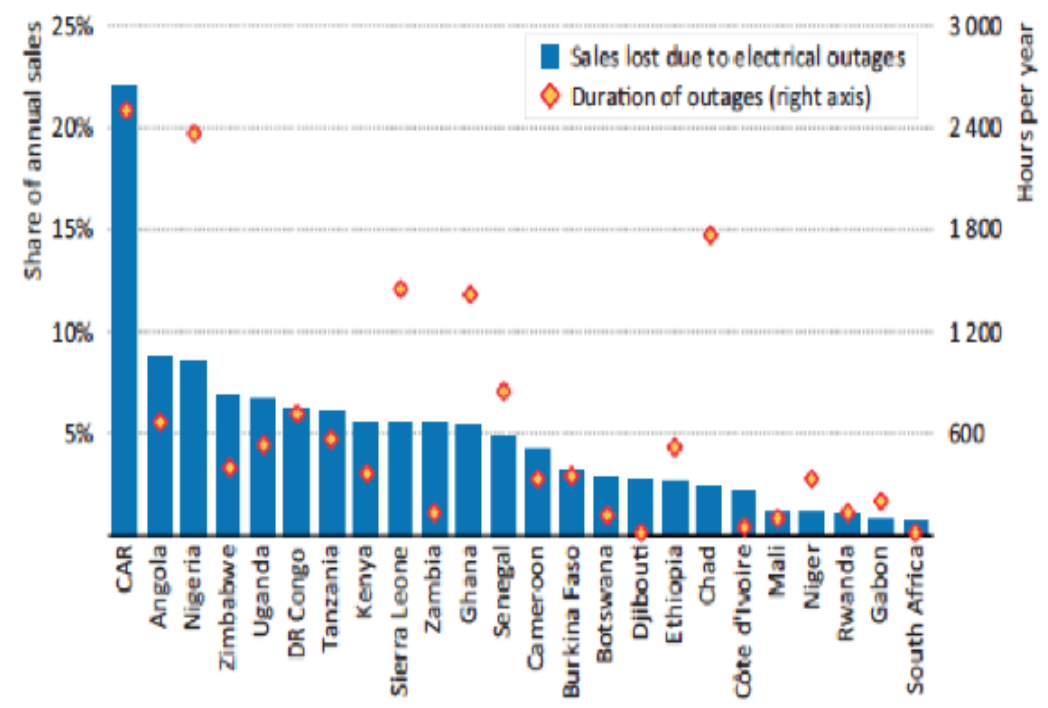

Fig. 2 Duration of electrical outages and impact on business sales in Nigeria compared to some other African countries [20].

This lack of appropriate development of the power sector has led to several allegations of mismanagement since 1999 as can be seen in literature [17,20-24]. Incidents of mismanagement are still reported in the DisCos even though they are now privatized [25]. This is responsible for the continued use of the "estimated billing system" to bill a majority of the electricity consumers in Nigeria since the privatization of the DisCos. Instead of making efforts to meter customers, the DisCos have continued to undermine efforts made by the government to ensure that electricity consumers in the country are properly metered.

\section{Estimated Billing System in Nigeria}

The estimated billing system for electricity was introduced in Nigeria by the NERC to ensure that the DisCos have a way of billing the unmetered customers, and customers whose meters are faulty or inaccessible to the DisCos officials during reading times. To further ensure that the estimated bills are not arbitrarily hiked by the DisCos, NERC by section 96 of the Electric Power Sector Reform Act of Nigeria, 2005, established a regulation on the methodology for the estimated billing system, in the year 2012 [26]. The regulation stipulates that all metered customers whose meters are not accessible during reading time or faulty shall be billed based on their last 
actual reading obtained until another reading is established. When a new reading is established, reconciliation shall be carried out to determine whether the customer was overbilled or under-billed, and make the necessary adjustments (in terms of credit or debit) in the subsequent bills to the customer.

For the unmetered Maximum Demand (MD) Customer, they shall be billed based on the "Load Measurement Method" and the formula for their electricity consumption estimation is given by equation (1).

$C_{E}(k W h)=1000 \sqrt{3} V_{L} I_{L} P F A_{V} L F$

Where, $V_{L}$ is the line voltage in Volts, $I_{L}$ is the line current in Amperes, PF is the power factor, LF is the load factor, and $A v$ is the number of hours of power supply availability in a month.

The amount payable is now determined from equation (2).

Amount Payable $=\left(T_{C R} \times C_{E}\right)+F_{C}+V A T$

Where, $T_{C R}$ is the tariff class rate, $C_{E}$ is the energy consumption in $\mathrm{kWh}, F_{\mathrm{C}}$ is the fixed charge, and VAT is the value added tax.

For the Unmetered Non-MD Customers, their bill estimation shall be based on the "Weighted Average Cluster Load" and the formula is as given in equation (3).

$Z_{U}=\alpha\left(0.82 Z-Z_{M}\right)$

or

$Z_{U}=\alpha\left(0.72 X-Z_{M}\right)$

Where, $Z_{U}$ is the total energy for the unmetered customers, $Z_{\mathrm{M}}$ is the energy consumed by metered customers (both prepaid and manually read), $Z$ is the total energy available for billing after subtracting distribution and technical losses from $X, X$ is the total grid energy supplied to a DisCos, and $\alpha$ is the availability factor, which is the number of hours the feeder is ON, divided by the total number of hours in the billing cycle.

The energy consumed by a customer per class of unmetered customers $\left(Z_{\mathrm{Ci}}\right)$ is then determined from equation (4).

$Z_{C i}=L_{C}\left(\frac{Z_{U}}{N_{C}}\right)$

Where, $N_{c}$ is the number of customers in the class being considered in the feeder, and $L_{c}$ is the proportion of the load consumed per customer class based on a historical figure per feeder.

Lc is calculated from equation (5).

$L_{C}=\frac{N_{a} C_{a}}{\sum_{i}^{n} N_{i} C_{i}}$

Where, $N_{a}$ is the number of customers of a class in the feeder, $C_{a}$ is the average consumption or load of a class in the feeder, and $\sum_{i}^{n} N_{i} C_{i}$ is the total consumption of all classes in the feeder.

The energy consumed by a customer per class is then multiplied by the tariff rate of the class, and the fixed charge and VAT added to determine the amount each customer in the class is to pay. The tariff rate of each customer class is provided in the Multi-Year Tariff Order (MYTO) of each DisCo as approved by NERC [27]. Table 3 shows the different classes of electricity consumers in Nigeria while Table 4 gives the MYTO for EEDC.

Table 3 Nigerian electricity tariff classes [27].

\begin{tabular}{|c|c|c|}
\hline Customer classification & Description & Remarks \\
\hline \multicolumn{2}{|l|}{ Residential } & \multirow{5}{*}{$\begin{array}{l}\text { A consumer who uses his premises exclusively as a } \\
\text { residence - house, flat or multi-storied house. }\end{array}$} \\
\hline R1 & Life-Line (50 kWh) & \\
\hline R2 & Single and 3 -phase & \\
\hline R3 & LV MD & \\
\hline R4 & HV MD $(11 / 33$ kV) & \\
\hline \multicolumn{2}{|l|}{ Commercial } & \multirow{4}{*}{$\begin{array}{c}\text { A consumer who uses his premises for any purpose } \\
\text { other than exclusively as a residence or as a factory } \\
\text { for manufacturing goods. }\end{array}$} \\
\hline $\mathrm{C} 1$ & Single and 3-phase & \\
\hline $\mathrm{C} 2$ & LV MD & \\
\hline $\mathrm{C} 3$ & HV MD (11/33 kV) & \\
\hline \multicolumn{2}{|l|}{ Industrial } & \multirow{4}{*}{$\begin{array}{l}\text { A consumer who uses his premises for } \\
\text { manufacturing goods including welding and } \\
\text { ironmongery. }\end{array}$} \\
\hline D1 & Single and 3-phase & \\
\hline D2 & LV MD & \\
\hline D3 & HV MD (11/33 kV) & \\
\hline \multicolumn{2}{|l|}{ Special } & \multirow{5}{*}{$\begin{array}{l}\text { Customers such as agriculture and agro-allied } \\
\text { industries, water boards, religious houses, } \\
\text { government and teaching hospitals, government } \\
\text { research institutes, and educational establishments. }\end{array}$} \\
\hline A1 & Single and 3 Phase & \\
\hline A2 & LV MD & \\
\hline A3 & HV MD (11/33 kV) & \\
\hline \multicolumn{2}{|l|}{ Street Lighting } & \\
\hline $\mathrm{S} 1$ & Single and 3-phase & \\
\hline
\end{tabular}


Table 4 Nigerian MYTO - Enugu Disco tariffs in Nigerian Naira (NGN)/kWh.

\begin{tabular}{ccccccccccc}
\hline Class & $\mathbf{2 0 1 5}$ & $\mathbf{2 0 1 6}$ & $\mathbf{2 0 1 7}$ & $\mathbf{2 0 1 8}$ & $\mathbf{2 0 1 9}$ & $\mathbf{2 0 2 0}$ & $\mathbf{2 0 2 1}$ & $\mathbf{2 0 2 2}$ & $\mathbf{2 0 2 3}$ & $\mathbf{2 0 2 4}$ \\
\hline R1 & 4.00 & 4.00 & 4.00 & 4.00 & 4.00 & 4.00 & 4.00 & 4.00 & 4.00 & 4.00 \\
R2S & 16.44 & 27.13 & 30.93 & 31.00 & 22.91 & 20.99 & 21.01 & 20.76 & 20.63 & 20.46 \\
R2T & 16.44 & 27.13 & 34.28 & 34.36 & 25.40 & 23.27 & 23.29 & 23.01 & 22.87 & 22.68 \\
R3 & 31.26 & 45.10 & 48.12 & 48.23 & 35.65 & 32.66 & 32.70 & 32.30 & 32.10 & 31.84 \\
R4 & 31.26 & 43.19 & 46.08 & 46.19 & 34.14 & 31.28 & 31.31 & 30.93 & 30.74 & 30.49 \\
C1S & 23.05 & 32.13 & 34.28 & 34.36 & 25.40 & 23.27 & 23.29 & 23.01 & 22.87 & 22.68 \\
C1T & 23.05 & 36.78 & 39.25 & 39.34 & 29.08 & 26.64 & 26.67 & 26.34 & 26.18 & 25.97 \\
C2 & 29.05 & 42.40 & 45.24 & 45.35 & 33.52 & 30.71 & 30.74 & 30.36 & 30.18 & 29.94 \\
C3 & 29.05 & 42.97 & 45.85 & 45.96 & 33.97 & 31.12 & 31.15 & 30.77 & 30.59 & 30.34 \\
D1S & 23.44 & 37.83 & 40.37 & 40.46 & 29.91 & 27.40 & 27.43 & 27.09 & 26.93 & 26.71 \\
D1T & 23.44 & 38.68 & 42.56 & 42.66 & 31.54 & 28.89 & 28.92 & 28.57 & 28.39 & 28.16 \\
D2 & 30.45 & 42.80 & 45.67 & 45.77 & 33.83 & 31.00 & 31.03 & 30.65 & 30.46 & 30.22 \\
D3 & 30.45 & 43.89 & 46.83 & 46.94 & 34.70 & 31.79 & 31.82 & 31.43 & 31.24 & 30.99 \\
A1S & 25.81 & 32.01 & 34.16 & 34.24 & 25.31 & 23.18 & 23.21 & 22.92 & 22.79 & 22.60 \\
A1T & 25.81 & 36.78 & 39.25 & 39.34 & 29.08 & 26.64 & 26.67 & 26.34 & 26.18 & 25.97 \\
A2 & 25.81 & 42.41 & 45.26 & 45.36 & 33.53 & 30.72 & 30.75 & 30.37 & 30.19 & 29.95 \\
A3 & 25.81 & 42.23 & 45.06 & 45.16 & 33.38 & 30.58 & 30.61 & 30.24 & 30.06 & 29.81 \\
L1 & 19.79 & 30.79 & 32.86 & 32.94 & 24.34 & 22.30 & 22.33 & 22.05 & 21.92 & 21.74 \\
\hline
\end{tabular}

This is the methodology for the estimated billing of unmetered electricity consumers in Nigeria. The DisCos refused to follow this methodology but instead resorted to an arbitrary billing system. They fail to read the meter of customers with analog meter and arbitrarily bill both these customers and those without meter. When they refuse to pay the outrageous bills, their power lines are disconnected and they are made to pay reconnection fees together with the bills [28]. The regulatory body, NERC, is also culpable as they failed to sternly enforce the regulation. Because electricity consumers are billed arbitrarily and most of them don't even know that NERC forums exist where they can seek redress, they resort to energy wastage. They use high energy-consuming devices even though they knew that the low energy alternatives of such devices exist [29]. This gives rise to high energy demand on the weak distribution lines and equipment of the DisCos. This fact, coupled with the DisCos deliberate rejection of power supplied to them by the Transmission Company of Nigeria (TCN), is the major cause of the erratic power supply in Nigeria [30-35].

\section{DisCos Preference for Estimated Billing System Over Prepaid Metering System}

The smart prepaid metering system is the best option to adopt in the billing of electricity consumers [36-38]. Despite the numerous benefits of the prepaid smart metering system to both the DisCos and their customers, the DisCos still preferred the estimated billing system, which their customers see as exploitative, and have therefore condemned it at every given opportunity. The Nigerian masses even want the estimated billing to be criminalized [39]. After failed attempts at getting the DisCos to adequately meter their customers, NERC has now abolished the estimated billing system and capped the maximum amount every unmetered customer in each tariff class is to be billed every month $[40,41]$. Table 5 shows the NERC approved monthly energy billing cap for EEDC. But the DisCos have rejected the order, citing errors by NERC in computing the figures [42]. 
Table 5 The NERC approved monthly energy billing cap for EEDC.

\begin{tabular}{|c|c|c|c|c|}
\hline \multicolumn{5}{|c|}{ Monthly energy cap } \\
\hline \multirow[t]{2}{*}{ Business unit } & \multicolumn{4}{|c|}{ Tariff class } \\
\hline & R2S (kWh) & R2T (kWh) & C1S (kWh) & $\mathrm{C} 1 \mathrm{~T}(\mathrm{kWh})$ \\
\hline Aba & 90 & 436 & 112 & 202 \\
\hline Abakaliki & 85 & 188 & 86 & 95 \\
\hline Abakpa & 80 & 162 & 112 & 158 \\
\hline Ariaria & 80 & 167 & 154 & 98 \\
\hline Awka & 79 & 185 & 106 & 182 \\
\hline Awkunanaw & 82 & 164 & 115 & 218 \\
\hline Ekwulobia & 97 & 280 & 66 & 97 \\
\hline Mbaise & 67 & 371 & 66 & 114 \\
\hline New Owerri & 60 & 356 & 93 & 176 \\
\hline Nnewi & 83 & 258 & 94 & 437 \\
\hline Nsukka & 74 & 118 & 84 & 188 \\
\hline Ogbaru & 60 & 80 & 60 & 241 \\
\hline Ogidi & 60 & 86 & 84 & 146 \\
\hline Ogui & 67 & 362 & 156 & 340 \\
\hline Onitsha & 114 & 179 & 77 & 179 \\
\hline Orlu & 66 & 346 & 66 & 97 \\
\hline Owerri & 95 & 153 & 88 & 207 \\
\hline Umuahia & 70 & 584 & 91 & 263 \\
\hline
\end{tabular}

The energy cap with the approved tariff became effective on $20^{\text {th }}$ February 2020. It includes R2S at NGN 30.93 (0.08 USD) per kWh, R2T at NGN 34.28 (0.09 USD) per kWh, C1S at NGN 34.28 (0.09 USD) per kWh, and C1T at NGN 39.25 (0.10 USD) per kWh.

This study seeks to empirically evaluate the major incentive responsible for the DisCos efforts at continuing with the estimated billing system.

\section{Materials and Methods}

For this study, four EEDC customers occupying the four 3-bedroom flats in a building located at Obinze and within the New Owerri business district of EEDC were selected. These EEDC customers were given estimated bills by EEDC for many years despite having functional analog meters. They kept complaining to EEDC by officially writing their customer complaint unit on several occasions but nothing was done until they took the matter to NERC, Owerri Forum in 2017. EEDC in a bid to save its face claimed that the four analog meters were faulty. They quickly replaced the meters with prepaid meters to avoid verification of their faulty meters claim but added a huge amount of debts into the prepaid meter accounts as the money these customers owed the company from their previous estimated bills. A picture of the four analog meters is shown in Fig. 3 while that of the smart meters is shown in Fig. 4.
Using the estimated bills given to these customers by EEDC for 12 months, the total estimated bill which each of them was given in a year was determined and recorded. With the 12 months smart meter prepaid bill statements of the customers, the total prepaid meter bill per year for each of the customers under the prepaid meter era was also determined and recorded. The results of the estimated bill era were compared with those of the prepaid meter and inference made.
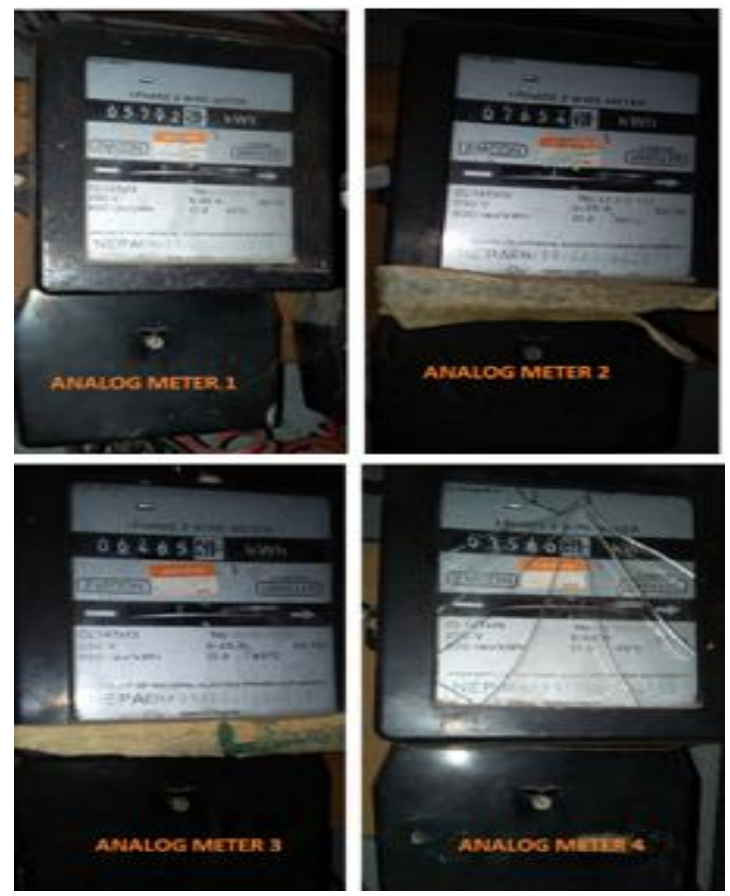

Fig. 3 Picture of the 4 customers' analog meters. 


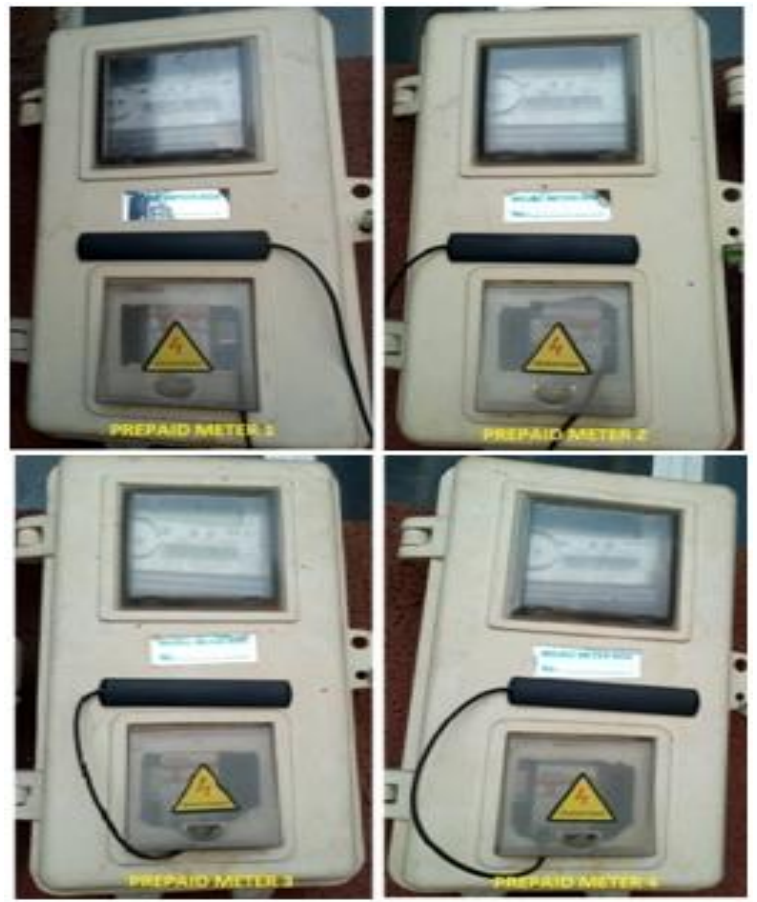

Fig. 4 Picture of the 4 customers prepaid meters.

\section{Results and Discussion}

The one-year monthly estimated bills and prepaid meter bills data for each of the four customers were used to prepare a chart to visualize the estimated bills and prepaid bills' monthly levels. The charts also show the monthly variations between the estimated bills and prepaid bills. Figs. 5 to 8 are the charts of the monthly estimated bills and prepaid meter bills for the four customers, respectively. From these charts, it can be seen that EEDC never followed the estimated bill methodology in billing these customers [26]. They did not apply the rule that stipulates that all customers with analog meters should be given bills based on the actual reading of their meters and where the meters could not be

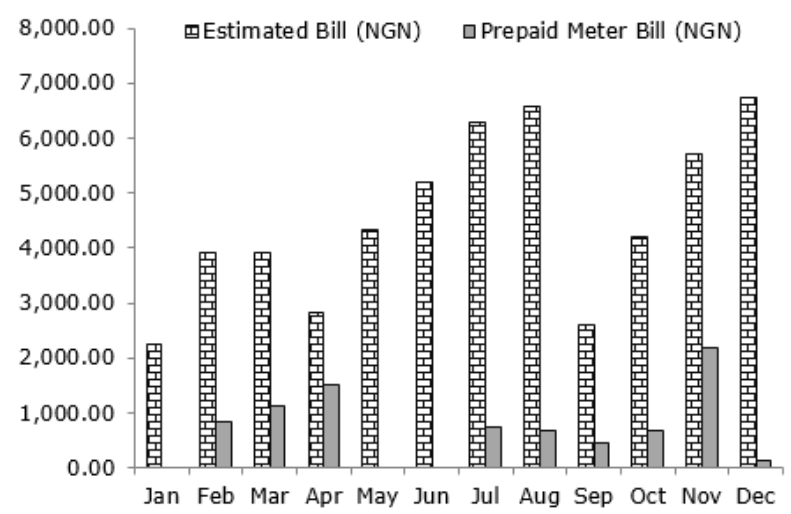

Fig. 5 The one-year monthly estimated bills and prepaid meter bills for customer 1 .

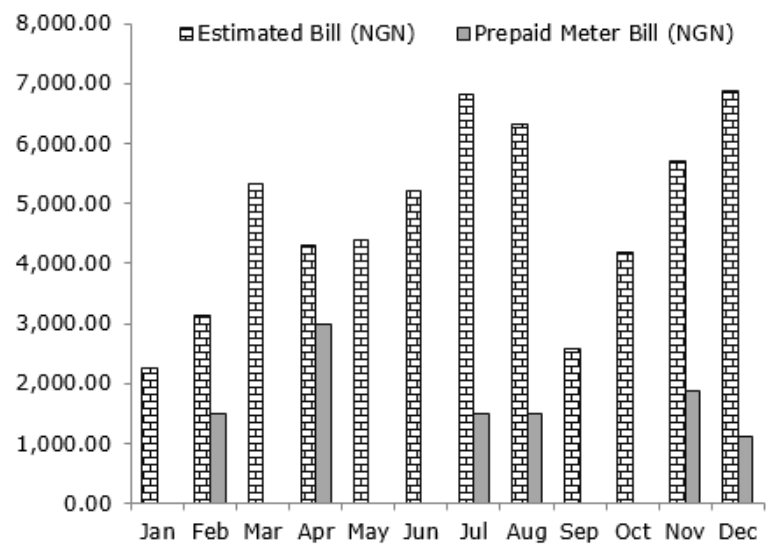

Fig. 6 The one-year monthly estimated bills and prepaid meter bills for customer 2 .

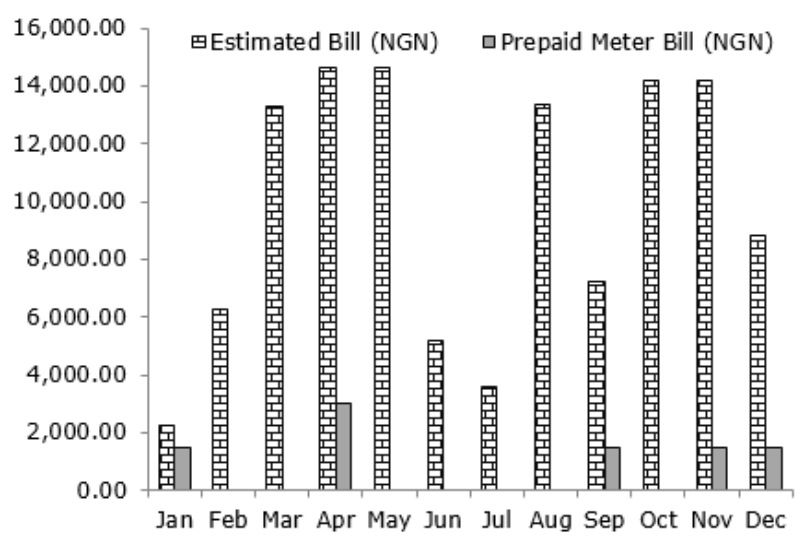

Fig. 7 The one-year monthly estimated bills and prepaid meter bills for customer 3 .

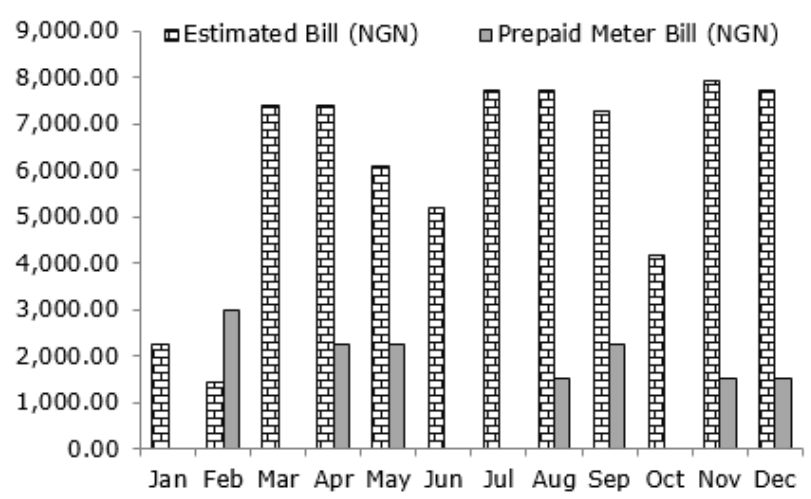

Fig. 8 The one-year monthly estimated bills and prepaid meter bills for customer 4 .

read, the last actual reading should be used to bill the customers until such a time that a new reading is obtained. If this rule was applied, there would have been several consecutive months with the same bill amount as the analog meters were not read for months. EEDC also did not apply the rule that governs the billing of unmetered customers. If they did, the four customers would have had the same bill amount for all the months because 
they were on the same R2S tariff class and the estimated billing methodology stipulates that all customers on the same tariff class and the same area should be billed equally. On the other hand, the monthly discrepancies between the estimated bills and prepaid bills are humongous in most of the months giving clues to the main reason why the DisCos preferred the estimated billing system (or arbitrary billing system as they made it look).

A chart was also prepared with the total one year estimated bills and prepaid bills of the customers. This is shown in Fig. 9. This chart shows a very large difference between the total bills these customers got under the estimated bills era when compared to the ones under the prepaid bill's era. The customer with the highest total estimated bills was the second-lowest consumer of electricity under the prepaid smart metering system.

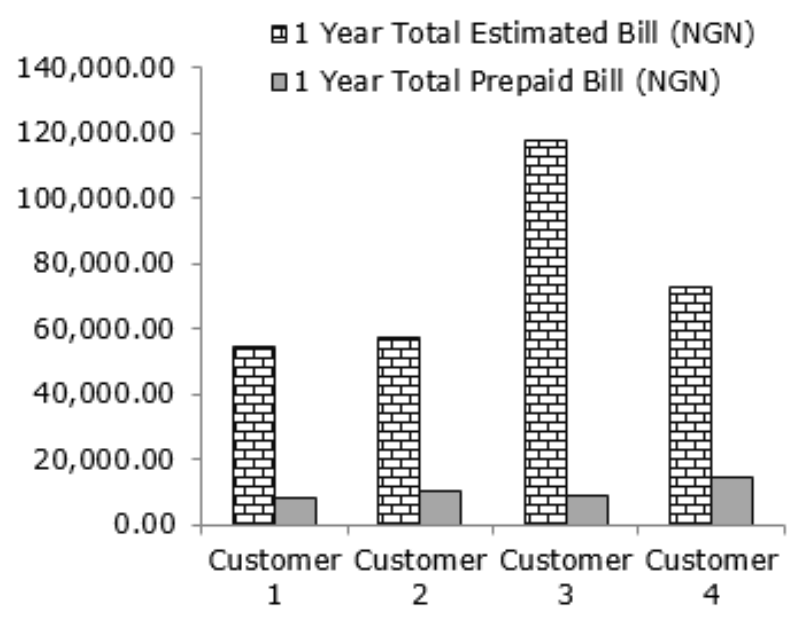

Fig. 9 The one-year total estimated bills and prepaid bills of the 4 customers.

The one-year total estimated bills of each of the 4 customers were determined as NGN 54548.4 (143.55 USD) for customer 1, NGN $57,140.16$ (150.37 USD) for customer 2, NGN $117,625.05$ (309.54 USD) for customer 3 , and NGN 72,368.06 (190.44 USD) for customer 4 while the one-year total prepaid meter bills were determined as NGN 8,325 (21.91 USD), NGN 10,500 (27.63 USD), NGN 9,000 (23.68 USD), and NGN 14,250 (37.50 USD), respectively. The one-year total estimated bills for each of the customers were found to be greater than the prepaid bills by NGN 46223.40 (555\%), NGN 46640.16 (444\%), NGN $108625.05(1,207 \%)$, and NGN $58118.06(408 \%)$, respectively. The total one-year estimated bill of the 4 customers was calculated as NGN 301,681.67 (793.90 USD) and the average per customer was determined as NGN 75,420.42 (198.47 USD), while the total one-year prepaid bill of the 4 customers was calculated as NGN 42,075.00 (110.72 USD) and the average per customer was determined as NGN 10,518.75 (27.68 USD). The total one-year estimated bill of the 4 customers was, therefore, greater than the total prepaid bill by NGN 259,606.69 (617\%) with the average over-billing per customer as NGN 64,901.67 (617\%).

\section{Conclusions and Policy Implications}

From the empirical results of this research, EEDC was found to be overbilling the four customers under the estimated billing system by a yearly average per customer of NGN $64,901.67$ (170.79 USD). This implies that for one million customers under the estimated billing system, EEDC (and possibly every other DisCo) could be making about 64.9 billion Nigerian Naira (170.8 million US dollars) over what they would have made if the customers were properly metered and billed. This is, perhaps, the reason why the DisCos refused to properly meter their customers and made efforts to frustrate every move by NERC to ensure that electricity consumers in Nigeria are properly metered with the use of smart prepaid meters.

Under the estimated billing system, which the DisCos converted to an arbitrary or a criminal billing system as they failed to use the stipulated formula for the bill estimation, the DisCos were making a huge amount of money whether they supplied electricity to the customers or not. They could even supply electricity to their customers for only two hours in a month and still bill them hugely. This made the DisCos on several occasions; deliberately reject electric power supplied to them by TCN. The implication of this is businesses in Nigeria having regular power outages and therefore heavy losses, which have made many of them (like Afprint Nig. Plc, Pacific Weaving Coy Ltd, Vinkay Industries Nig. Ltd, Blanket Manufacturing Co. Ltd, Aba Textile Mills Ltd, etc.) fold up over the years. Many jobs have therefore been lost as a result of this and new investors from within and outside the country are scared of investing in Nigeria.

The outrageous bills given by the DisCos to even customers using low energy consuming devices made most of the customers under the estimated billing system resort to energy wastage by using high energy-consuming devices like incandescent bulbs and cathode ray tube (CRT) televisions instead of the low energy alternatives like the Light Emitting Diode (LED) bulbs and televisions. They also 
leave these devices ON even when they are not needed. The consequence of this is a constant heavy load on the weak transmission lines and equipment of the DisCos which causes power instability and therefore, the erratic power supply in Nigeria is a result of this.

The Nigerian Electricity Regulatory Commission (NERC) is hereby called upon to ensure that the DisCos meter their customers appropriately. This will force the DisCos to sit up and invest in their businesses which they refused to do over the years as a result of making money from doing nothing. With a majority of the electricity consumers using smart prepaid meters and those without meters billed under the NERC new Capped Billing System, the DisCos will ensure regular power supply to their customers as the money they will be making from their business will now depend on the electricity supplied. They will start looking for more power supplies from TCN instead of rejecting the power supplied to them. This will help revive the dying companies and industries in Nigeria, help new ones to start up and grow, and thereby create and sustain new jobs, and generally help the economy to flourish.

\section{Conflict of Interests}

The author declares that there is no conflict of interests regarding the publication of this paper.

\section{Acknowledgment}

The author hereby thanks and acknowledges the help offered by the EEDC customers whose bills and meters were used for this research. I also thank the NERC Forum Owerri officials whose influence made EEDC replace the analog meters with prepaid meters. This research was self-funded. I, therefore, thank greatly the Almighty God Who made it a reality.

\section{ORCID}

A. C. Ohajianya (i) https://orcid.org/0000-0003-2452-1209

\section{References}

[1] A. C. Ohajianya, O. E. Abumere, I. O. Owate, and E. Osarolube, "Erratic power supply in Nigeria: Causes and solutions," Int. J. Eng. Sci. Invent., vol. 3, no. 7, pp. 51-55, 2014.

[2] S. D. Fabiyi, A. O. Abdulmalik, and H. A. Tiamiu, "Dwindling electrical power supply in Nigeria: Causes and possible solutions," Int. J. Sci. Res., vol. 5, no. 5, pp. 635-639, 2015.

[3] C. Agbeboaye, F. O. Akpojedje, and B. I. Ogbe, "Effects of erratic and epileptic electric power supply in Nigerian telecommunication industry: Causes and solutions," J. Adv. Sci. Eng., vol. 2, no. 2, pp. 29-35, 2019.

[4] C. O. Osueke and C. T. Ezeh, "Assessment of Nigeria power sub-sector and electricity generation projections," Int. J. Sci. Eng. Res., vol. 2, no. 11, pp. 1-7, 2011.

[5] H. O. Onyi-Ogele, "The implications of legal reform in the Nigeria power sector," Afr. Res. Rev., vol. 10, no. 3, pp. 279-289, 2016.

[6] V. K. Abanihi, S. O. Ikheloa, and F. Okodede, "Overview of the Nigerian power sector," Am. J. Eng. Res., vol. 7, no. 5, pp. 253-263, 2018.

[7] U. P. Onochie, H. O. Egware, and T. O. Eyakwanor, "The Nigeria electric power sector (opportunities and challenges)," $J$. Multidiscip. Eng. Sci. Technol., vol. 2, no. 4, pp. 494-502, 2015.

[8] O. I. Okoro, P. Govender, and E. Chikuni, "Power sector reforms in Nigeria: Opportunities and challenges," in Proceeding for 10th International Conference on the Domestic Use of Energy, Cape Town/South Africa, 2006, pp. 29-34.

[9] O. I. Okoro and E. Chikuni, "Power sector reforms in Nigeria: Opportunities and challenges," J. Energy South. Africa, vol. 18, no. 3, pp. 52-57, 2007.

[10] A. A. Sambo, B. Garba, and M. M. Magaji, "Electricity generation and the present challenges in the Nigerian power sector," in The 2010 world energy Congress of the world energy Council, Montreal, Canada, 2010.

[11] L. Cheri and A. Ibrahim, "An assessment of the challenges and prospects of power sector reform in Nigeria from 2000-2013," Rev. Arts Humanit., vol. 2, no. 1, pp. 1-37, 2013.

[12] A. S. Aliyu, A. T. Ramli, and M. A. Saleh, "Nigeria electricity crisis: Power generation capacity expansion and environmental ramifications," Energy, vol. 61, pp. 354-367, 2013.

[13] P. O. Olalere, "Privatization of electricity industry in Nigeria: Lessons from Europe and United States of America," Renew. Energy Law Policy J., vol. 5, no. 2, pp. 136-149, 2014.

[14] NERC, "Power generation in Nigeria," Nigerian Electricity Regulatory Commission, 2020. [Online]; https://nerc.gov.ng/index.php/ home/nesi/403-generation\# [Accessed: 06Apr-2020].

[15] NERC, "Distribution companies," Nigerian Electricity Regulatory Commission, 2020. [Online]; https://nerc.gov.ng/index.php/ contact/discos [Accessed: 06-Apr-2020].

[16] B. Nnaji, "Power sector outlook in Nigeria: Government renewed priorities," Securities and Exchange, 2011.

[17] U. E. Abraham and H. D. Bello, "Corruption in the privatized electricity companies in Nigeria: Its implication on the socioeconomic development of Uyo Metropolis," South-South J. Cult. Dev., vol. 19, no. 1, pp. 1-27, 2017. 
[18] K. Sanni, "Nigerian govt spent N1.5 trillion on power sector in two years - Osinbajo," Premium Times, 26-Sep-2019.

[19] EIA, "Independent statistics and analysis," U.S. Energy Information Administration, 2020. [Online], https://www.eia.gov/ international/overview/country/NGA [Accessed: 04-May-2020].

[20] E. K. Ogunleye, "Political economy of Nigerian power sector reform," World Institute for Development Economics Research, March, pp. 1-29, 2016.

[21] SERAP, "From darkness to darkness: How Nigerians are paying the price for corruption in the electricity sector," Socio-Economic Rights and Accountability Project (SERAP), no. August. 2017.

[22] D. Ojerinde, "How corruption crippled Nigeria's power sector - Report," PUNCH, 20Sep-2019.

[23] N. Lawal, "Nigeria has lost N11trn to corruption in the power sector since 1999 Report," Legit, $2019 . \quad$ [Online] https://www.legit.ng/1260568-powersector-corruption-nigeria-lost-n11trn-1999--report.html [Accessed: 04-May-2020].

[24] A. Olukoju, "Never expect power always: Electricity consumers' response to monopoly, corruption and inefficient services in Nigeria," Afr. Aff. (Lond)., vol. 103, no. 410, pp. 5171, 2004.

[25] SDN, "Electricity sector corruption perception index 2017: Promoting accountability in Nigeria' S electricity sector," Stakeholder Democracy Network, 2017, [Online], https://www.stakeholderdemocracy.org/wpcontent/uploads/2018/04/BEDC-corruptionindex.pdf [Accessed: 05-May-2020].

[26] NERC, "Methodology for estimated billing," Nigerian Electricity Regulatory Commission, Nigeria, 2012.

[27] NERC, "MYTO-2015 distribution tariffs (20152024) effective 1st February 2016," Nigerian Electricity Regulatory Commission, December, pp. 1-14, 2015.

[28] M. U. Anyaehie, S. U. Nwadike, and O. C. Iwuamadi, "The implications of estimated billing system on Nigerian electricity consumers," Am. J. Eng. Res., vol. 7, no. 4, pp. 169-175, 2018.
[29] D. F. Arawomo, "Electricity billing systems and household electricity use behavior in Ibadan, Nigeria," Energy Sustain. Dev., vol. 40, pp. 77-84, 2017.

[30] O. Nnodim, "Discos reject 17,657MW as power outage persists," PUNCH, Abuja, 04Mar-2020.

[31] O. Nnodim, "Discos reject 5,451MW of electricity in one week," PUNCH, Abuja, 27Jan-2020.

[32] O. Bello, "Blame game continues between TCN and Discos overload rejection," Businessday NG, 22-Sep-2019.

[33] O. Bello, "Update: Discos' rejection of electricity allocation may because of system collapse," Businessday NG, 17-Jan-2020.

[34] E. Alike and C. Okafor, "NERC probes alleged power rejection by Discos," THISDAYLIVE, 24-Sep-2019.

[35] O. Nnodim, "Consumers condemn rejection of electricity by DisCos," Nigeria Electricity Hub, 03-Feb-2020.

[36] K. Kundeti and S. Pallagani, "Smart electricity billing system," Int. J. Eng. Manag. Res., vol. 6, no. 3, pp. 526-529, 2016.

[37] M. J. Alam and F. M. Shahriar, "Electricity billing systems at residential level in Sylhet City: Is pre-paid system perceived as a better option by the subscribers?" Ind. Eng. Lett., vol. 2, no. 3, pp. 45-61, 2012.

[38] M. Mhereeg, A. A. Zongo, M. Shlebik, A. Fadel, and A. Elghadi, "The automation of the billing system in GECOL using smart metering services," in Libyan International Conference on Electrical Engineering and Technologies (LICEET2018) 3 - 7 March 2018, Tripoli, Libya The, 2018, pp. 274-279.

[39] THISDAY, "Criminalising estimated billing system," Thisdaylive, 05-Feb-2019.

[40] NERC, "The order on the capping of estimated bills in the Nigerian electricity supply industry," Nigerian Electricity Regulatory Commission, Nigeria, 2020.

[41] A. Sanyaolu, "NERC abolishes estimated billing by Discos," The Sun Nigeria, 25-Feb2020.

[42] E. Ejoh, S. Obiakor, and F. Ologunde, "Electricity tariff hike: DisCos reject NERC directive on estimated billing," Vanguard $\mathrm{Ng}$, 06-Mar-2020. 